\title{
A New Tymovirus Isolated From Solanum quitoense: Characterization and Prevalence in Two Solanaceous Crops in Ecuador
}

\author{
Juan F. Cornejo-Franco, ${ }^{1}$ Robert A. Alvarez-Quinto, ${ }^{2}$ Samuel Grinstead, ${ }^{3}$ Dimitre Mollov, ${ }^{3}$ Alexander V. Karasev, ${ }^{4}$ \\ Jose Ochoa, ${ }^{5,6}$ and Diego F. Quito-Avila ${ }^{1,7, \dagger}$ \\ ${ }^{1}$ Centro de Investigaciones Biotecnológicas del Ecuador, Escuela Superior Politécnica del Litoral, Campus Gustavo Galindo, \\ Guayaquil 090101, Ecuador \\ ${ }^{2}$ Department of Plant Pathology, University of Minnesota, St. Paul, MN 55108, U.S.A. \\ ${ }^{3}$ National Germplasm Resources Laboratory, U.S. Department of Agriculture Agricultural Research Service, Beltsville, MD \\ 20705, U.S.A. \\ ${ }^{4}$ Department of Entomology and Plant Pathology and Nematology, University of Idaho, Moscow, ID 83844-2329, U.S.A. \\ ${ }^{5}$ Instituto Nacional Autónomo de Investigaciones Agropecuarias, Quito 170101, Ecuador \\ ${ }^{6}$ Facultad de Ciencias Agrícolas, Universidad Central del Ecuador, Quito 170101, Ecuador \\ ${ }^{7}$ Facultad de Ciencias de la Vida, Escuela Superior Politécnica del Litoral, Campus Gustavo Galindo, Guayaquil 090101, \\ Ecuador
}

\begin{abstract}
Naranjilla (Solanum quitoense Lam.) and tamarillo (S. betaceum Cav.) are two important perennial solanaceous crops grown in Ecuador for the fresh market and juice production. Viruses infecting tamarillo and naranjilla are currently poorly studied, and no clean stock program exists in Ecuador. Here, we report a new virus, provisionally named as naranjilla mild mosaic virus (NarMMV) (genus Tymovirus, family Tymoviridae), isolated from naranjilla grown in an orchard in Pichincha Province, Ecuador. The complete genome of the virus consists of 6,348 nucleotides and encodes three open reading frames typical for members of the genus Tymovirus. Phylogenetically, Chiltepin yellow mosaic virus, Eggplant mosaic virus, and the recently characterized

naranjilla chlorotic mosaic virus (NarCMV) were found to be the closest relatives of NarMMV. Unlike NarCMV, the new virus induced mild mosaic in naranjilla and more severe symptoms in tamarillo. Similar to NarCMV, NarMMV was unable to systemically infect potato. Virus surveys found NarMMV prevalent in naranjilla production areas of two provinces of Ecuador, especially where hybrid cultivars of naranjilla were cultivated. NarMMV was also found in field-grown tamarillo. The new virus cross-reacted with antibodies developed against NarCMV. Hence, this antibody will be useful for its field diagnosis using enzymelinked immunosorbent assay or immunocapture reverse transcription polymerase chain reaction in future virus-free certification programs.
\end{abstract}

Naranjilla (Solanum quitoense Lam.) is a perennial herbaceous plant that is native to Ecuador and Colombia (Lim 2013). The plant produces edible fruits that resemble a small hairy orange. In Ecuador, the crop is grown between 1,500 and 2,400 m of altitude, especially in humid areas of the Amazon region. Naranjilla has long been consumed fresh for homemade juice and the fruit has also been used for local commercial bottled juice and ice cream production.

The production of naranjilla represents the main income source for thousands of Ecuadorean families. Insects and pathogen-related diseases hamper the sustainable production of this crop, especially soilborne pathogens such as Fusarium oxysporum and the root-knot nematode Meloidogyne spp. (Lim 2013; Monteros et al. 2004). Interspecific hybrids, such as the commonly grown Puyo ( $S$. sessiliflorun $\times S$. quitoense), that are resistant to these pathogens have mostly

${ }^{\dagger}$ Corresponding author: D. F. Quito-Avila; dquito@espol.edu.ec

Funding: This work was funded partially by the Centro de Investigaciones Biotecnológicas del Ecuador and also by the U.S. Department of Agriculture (USDA) Agricultural Research Service (grant 58-8042-6-049), the USDA National Institute of Food and Agriculture Hatch Funds (project IDA01560), and the Idaho Agricultural Experiment Station. This research was conducted under Genetic Resource Access Permit MAE-DNB-CM-2018-0098 granted by the Department of Biodiversity of the Ecuadorean Ministry of the Environment.

*The $\boldsymbol{e}$-Xtra logo stands for "electronic extra" and indicates that three supplementary figures and one supplementary table are published online.

The author(s) declare no conflict of interest.

Accepted for publication 27 March 2019.

() 2019 The American Phytopathological Society replaced the common naranjilla for production (Dennis et al. 1985; Heiser and Anderson 1999). The potential impact of viruses in naranjilla has not been considered until recently, when naranjilla chlorotic mosaic virus (NarCMV) was described from Ecuador (Green et al. 2018).

Tamarillo (S. betaceum Cav.) is a small perennial tree commonly cultivated in low-altitude mountains that surround areas where naranjilla is grown. Three main tamarillo skin types (red, orange, and purple) are known and usually referred to as cultivar groups, because they are not true cultivars. In Ecuador, the red tamarillo is the type of choice by consumers and is therefore the most commonly cultivated. Similar to naranjilla, tamarillo is produced mainly by small-scale farmers and the fruit is used for juices and sauces. Viral diseases affecting tamarillo are poorly studied, with only a few reported (Espinoza et al. 2017; Insuasti et al. 2016).

Here, we report a new tymovirus found naturally infecting naranjilla and tamarillo in Ecuador. The virus is provisionally named naranjilla mild mosaic virus (NarMMV) and is closely related to NarCMV. The objectives of this research were to characterize NarMMV at both the genomic and biological level and to investigate its prevalence in naranjilla and tamarillo orchards in Ecuador.

\section{Materials and Methods}

Virus origin. In 2017, leaves from a naranjilla plant (Puyo hybrid) showing mosaic symptoms were collected from a commercial orchard in Pichincha Province. The sample tested negative for potato virus Y (PVY), potato leafroll virus (PLRV), and the newly characterized NarCMV using reverse transcription polymerase chain reaction (RT-PCR) assays as previously described (Green et al. 2018; Insuasti et al. 2016). Symptomatic leaves were macerated in phosphate buffer (see the next section on host range studies) and used to mechanically inoculate red tamarillo seedlings, which were the 
only solanaceous plants available at the time of sampling. Inoculated plants were kept in an insect-proof cubicle under greenhouse conditions (natural light for $12 \mathrm{~h}$ per day and an average temperature of $25^{\circ} \mathrm{C}$ ) and used for host range experiments.

Host range studies. The host range of the naranjilla virus was tested, in triplicate, on the following plants: naranjilla, green pepper (Capsicum annuum 'Troner'), potato (S. tuberosum 'Super chola'), cape gooseberry (Physalis peruviana), eggplant (S. melongena 'Larga morada'), Nicotiana benthamiana, N. tabacum, and an orange-skinned type of tamarillo ( $S$. betaceum). Approximately $500 \mathrm{mg}$ of fresh symptomatic leaf tissue was homogenized in $5 \mathrm{ml}$ of $0.05 \mathrm{M}$ phosphate buffer ( $\mathrm{pH}$ 7.0) using a mortar and pestle. The homogenate was rubbed on young leaves previously dusted with 320-mesh silicon carbide (Hull 2009). Inoculated plants were kept in an insect-proof greenhouse and monitored for symptoms starting at 10 days postinoculation (dpi) for 8 weeks. At 30 dpi, both inoculated and noninoculated leaves were tested by RT-PCR using detection primers developed in this study (see the virus detection section in the Results).

Sequencing and genome analysis. Total RNA extracted from the greenhouse-inoculated tamarillo plants was used as input for highthroughput sequencing (HTS) at SeqMatic. The RNA extraction was done using a Qiagen RNA plant mini kit and the HTS was performed on a NextSeq 500 Illumina platform as single 75-bp reads. Sequence reads were processed and assembled into contigs by Qiagen CLC Workbench 9.0 (https://www.qiagenbioinformatics.com/ products/clc-main-workbench/).

In order to validate the HTS reads assembly, Sanger sequencing was performed on a series of overlapping RT-PCR fragments as described for NarCMV by Green et al. (2018). NarMMV-specific primers used for amplification of overlapping fragments and the terminal regions (see below) are presented in Supplementary Table S1. Purified PCR fragments were cloned using a pGEM-T Easy kit (Promega) and sequenced by Macrogen Inc. Terminal sequences were confirmed with a second-generation $5^{\prime} / 3^{\prime}$ RACE kit (Roche), using poly(A)-tailed total RNA according to the manufacturer's instructions.

For phylogenetic analyses, the complete genomes of members of the genus Tymovirus were obtained from the National Center for Biotechnology Information Genbank. Multiple sequence alignments using the coat protein $(\mathrm{CP})$ and replicase amino acid sequences were generated by MUSCLE (Edgar 2004) executed in MEGA 7 (Kumar et al. 2016). The best evolution model for each amino acid alignment was determined with MEGA 7 (Kumar et al. 2016) and used to infer phylogenies by the maximum likelihood algorithm.

Transmission electron microscopy. For electron microscopy, symptomatic common naranjilla leaves from the host range study were subjected to partial virus purification. Approximately $5 \mathrm{~g}$ of leaf material was ground in liquid nitrogen and 320-mesh silicon carbide until powdered. The powder was suspended in $0.5 \mathrm{M}$ of sodium phosphate buffer, $1 \mathrm{M}$ of urea, 5\% PVP40, and 0.5\% 2-mercaptoetanol at $\mathrm{pH}$ 7.4. The suspension was initially filtered through 50 Heavyweight Stabilizer (Pellon) and centrifuged at 19,800 $\times g_{\max }$ for $10 \mathrm{~min}$. Triton X-100 [5\% (vol/vol)] was added to the supernatant and shaken until foam formation, then layered by pipette over $30 \%$ sucrose cushion and centrifuged at $109,000 \times g_{\max }$ for $2.5 \mathrm{~h}$ at $10^{\circ} \mathrm{C}$. The pellet was resuspended in $0.5 \mathrm{ml}$ of $0.1 \mathrm{M}$ phosphate buffer at $\mathrm{pH}$ 7.4. After the addition of $0.5 \mathrm{ml}$ of chloroform, the samples were vortexed vigorously and centrifuged at $16,000 \times g_{\max }$ on a benchtop centrifuge. The supernatant was removed by pipetting into a new tube and used for grid preparations. Four-hundred-mesh formvar-coated copper grids (Electron Microscopy Sciences) were used for virion visualizations. Eight microliters of the partially purified virus was mixed with $2 \mu \mathrm{l}$ of $25 \%$ glutaraldehyde and incubated on the grids for $10 \mathrm{~min}$. Samples were washed with $2 \%$ sodium phosphotungstate $(\mathrm{pH} 7.0)$ four times and blotted dry on filter paper between each wash. Grids were visualized on a Hitachi 7700 electron microscope.

Detection and virus surveys. Between August 2017 and October 2018, virus prevalence was investigated by testing a total of 120 naranjilla (hybrid Puyo) and 90 tamarillo (red-type) plants sampled from four different family-owned orchards, ranging in size from 400 to $600 \mathrm{~m}^{2}$, in the provinces of Pichincha, Tungurahua, and Azuay. Approximately $500 \mathrm{mg}$ of the youngest, fully developed leaves, showing mosaic-like symptoms, were collected from at least 30 plants per orchard, following a zigzag pattern along the rows. Leaves were placed individually in plastic bags and transported on ice to the laboratory.

RT-PCR, using total RNA as the template, was used for virus detection as described (Halgren et al. 2007). Several primer pairs were designed based on the sequence from the HTS-derived viral contig and tested for the amplification efficiency of the new virus. PCR parameters were as follows: $94^{\circ} \mathrm{C}$ for $4 \mathrm{~min} ; 40$ cycles of $94^{\circ} \mathrm{C}$ for $45 \mathrm{~s}$, $55^{\circ} \mathrm{C}$ for $30 \mathrm{~s}$, and $72^{\circ} \mathrm{C}$ for $45 \mathrm{~s}$; and a final extension step of $10 \mathrm{~min}$ at $72^{\circ} \mathrm{C}$

In addition, an immunocapture (IC) RT-PCR assay was implemented as described previously (Chikh-Ali et al. 2013) using the coating antibodies developed for triple antibody sandwich (TAS)enzyme-linked immunosorbent assay (ELISA) detection of NarCMV (Green et al. 2018). Briefly, $100 \mu \mathrm{l}$ of the antibody solution (coating antibodies in $20 \mathrm{mM}$ of sodium carbonate buffer at 1:20,000 dilution) was added to each PCR tube and incubated at $37^{\circ} \mathrm{C}$ for $2 \mathrm{~h}$. Following a wash step, $100 \mu \mathrm{l}$ of tissue homogenate previously ground in extraction buffer at a 1:10 (wt/vol) rate was added to each coated tube and incubated at $37^{\circ} \mathrm{C}$ for $2 \mathrm{~h}$. After washing, $25 \mu \mathrm{l}$ of RT Master Mix was prepared with random hexamers using Maxima $\mathrm{H}$ Minus Reverse Transcriptase following the manufacturer's instructions (Thermo Fisher Scientific). For the PCR, $1 \mu$ l of the RT reaction was mixed with $9 \mu$ l of PCR mix containing Genscript Taq DNA polymerase and the specific primers developed in this study (see below).

For prevalence comparison purposes, total RNA extracts were also tested for NarCMV using the RT-PCR detection assay developed by Green et al. (2018).

\section{Results}

A first survey conducted at the beginning of 2017 using the RTPCR assay developed by Green et al. (2018) did not detect NarCMV in symptomatic Puyo naranjilla $(n=30)$ and red tamarillo $(n=20)$ collected from two different orchards in the provinces of Pichincha and Tungurahua, respectively. Additional tests were conducted based on earlier reports of other viruses in these plants (Insuasti et al. 2016), which revealed that $60 \%$ of all of the analyzed samples (naranjilla and tamarillo) tested positive for PVY and PLRV, either in single or mixed infections (not shown). Interestingly, one of the naranjilla samples that was negative for PVY, PLRV, and NarCMV showed a characteristic virus-like mosaic (Fig. 1). The work presented here reports a new tymovirus found in that sample.

Host range. The new virus systemically infected $N$. benthamiana, tamarillo, and eggplant, but not potato, cape gooseberry, pepper, or $N$. tabacum. In N. benthamiana, mosaic symptoms on upper, uninoculated leaves became visible at 12 dpi (Fig. 2A). In eggplant,

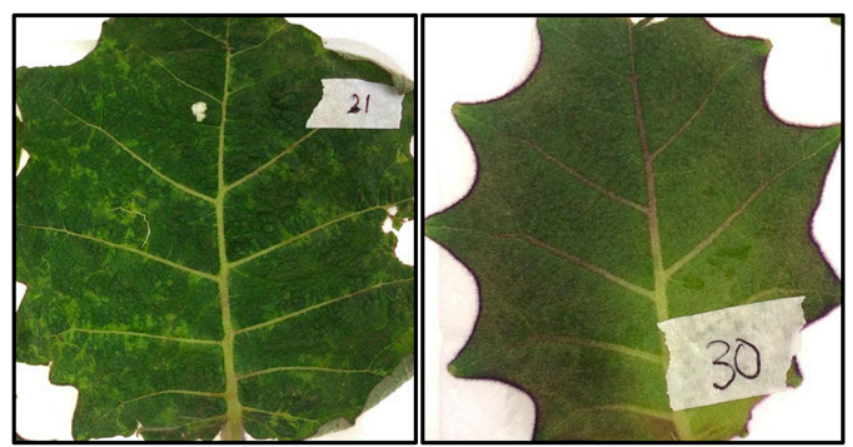

Fig. 1. Symptoms in field samples. The left image is a naranjilla leaf showing mild mosaic from the original source of naranjilla mild mosaic virus (NarMMV) compared with a symptomless NarMMV-free sample on the right. Original labels (21 and 30) are shown. 
chlorotic spots were visible at 18 dpi on inoculated leaves only (Fig. 2B), although systemic infection was confirmed by RT-PCR in upper, uninoculated symptomless leaves. The two tamarillo cultivars (red and orange) used in this study showed different responses to the virus. In the red cultivar, the virus induced severe leaf mottling, bunchy top, and intermittent tip necrosis followed by defoliation of the new leaves (Fig. 2C), whereas the orange cultivar, which tested positive by RT-PCR in uninoculated leaves, remained symptomless.
In the common naranjilla, the virus induced mild mosaic, first visible about 4 weeks postinoculation (Fig. 2D). Symptoms were transient, although the virus was continuously and readily detectable by RT-PCR or ELISA. Based on the subtle symptoms induced by the virus in common naranjilla, where the virus was first found, the NarMMV name is proposed. A summary of the plants tested for infectivity of NarMMV, and the symptoms associated with the virus, is presented in Table 1.

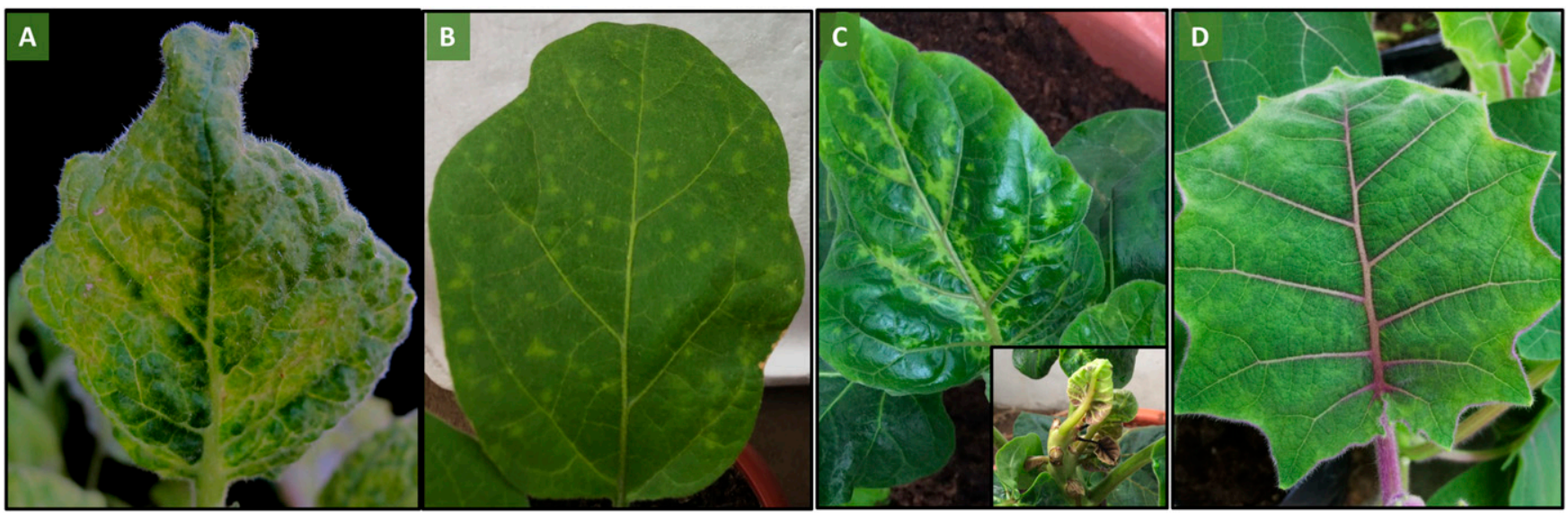

Fig. 2. Symptoms induced by naranjilla mild mosaic virus in mechanically inoculated hosts. A, Mosaic in Nicotiana benthamiana. B, Chlorotic spots in inoculated leaves of eggplant. C, Severe mosaic, along with necrosis of younger leaves (smaller panel), in red tamarillo. D, Mild mosaic observed in the common naranjilla.

Table 1. Summary of the results from host range experiments of naranjilla mild mosaic virus

\begin{tabular}{|c|c|c|c|c|c|}
\hline \multicolumn{2}{|l|}{ Host tested } & \multicolumn{2}{|c|}{ Symptoms $^{\mathbf{a}}$} & \multicolumn{2}{|c|}{ Virus detection (RT-PCR) ${ }^{\mathbf{b}}$} \\
\hline Scientific name & Common name, cultivar & Inoculated leaves & Uninoculated leaves & Inoculated leaves & Uninoculated leaves \\
\hline Solanum quitoense & Naranjilla, common & NS & Mild mosaic & + & + \\
\hline S. betaceum & Tamarillo, red type & NS & $\begin{array}{l}\text { Severe leaf mottling, } \\
\text { tip necrosis }\end{array}$ & + & + \\
\hline S. betaceum & Tamarillo, orange type & NS & NS & - & + \\
\hline S. tuberosum & Potato, super chola & NS & NS & - & - \\
\hline Physalis peruviana & Cape gooseberry & NS & NS & - & - \\
\hline S. melongena & Eggplant, Larga morada & Chlorotic spots & NS & + & + \\
\hline Nicotiana benthamiana & & NS & Mild mosaic & + & + \\
\hline N. tabacum & & NS & NS & - & - \\
\hline Capsicum аппиит & Pepper, troner & NS & NS & - & - \\
\hline
\end{tabular}

${ }^{\mathrm{a}} \mathrm{NS}=$ no symptoms.

b Plus signs indicate positive results and minus signs indicate negative results. RT-PCR $=$ reverse transcription polymerase chain reaction.

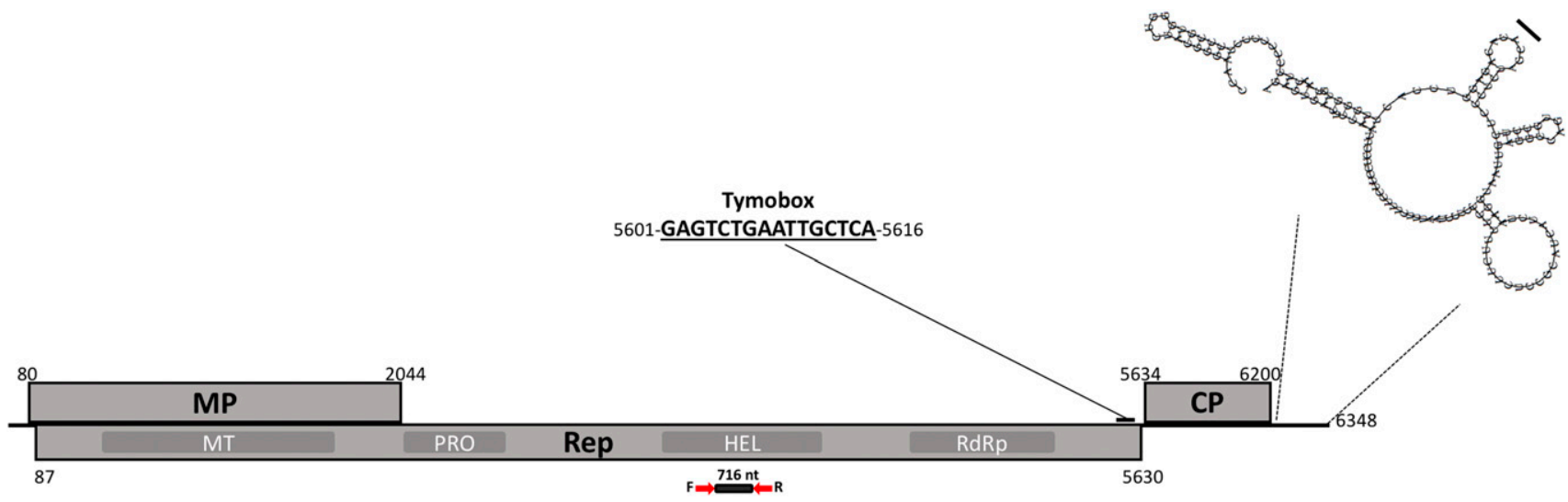

Fig. 3. Genome organization of naranjilla mild mosaic virus. Predicted open reading frames (ORFs) with nucleotide positions are shown by rectangular boxes containing the putative movement protein (MP), replicase (Rep), and the coat protein (CP), respectively. Conserved motifs for methyltransferase (MT), protease (PRO), helicase (HEL), and the RNA-dependent RNA-polymerase (RdRp) are indicated in shaded boxes within the Rep ORF. The 16-nucleotide (nt) conserved tymobox and the predicted secondary structure, formed at the $3^{\prime}$ terminal, are shown, where the valine (CAC) anticodon is indicated by a solid line in the loop. Detection primer sites (arrows) and the size of the amplification product are shown below the HEL region. 
Sequencing and genome analysis. HTS analysis produced $23,580,855$ raw data reads that assembled into 47,859 contigs. One contig of 6,300 nucleotides (nt) was related to chiltepin yellow mosaic virus (ChYMV). The contig coverage was on average 10,161 depth per nucleotide position. A total of 854,235 reads (3.6\%) were mapped to the viral-related contig.

The HTS-generated contig homologous to ChYMV, along with terminal regions, was reamplified using RT-PCR, and the sequence was confirmed by Sanger methodology. The complete genome consists of 6,348 nt with three open reading frames (ORFs) organized like other members of the genus Tymovirus (Fig. 3). The annotated sequence was deposited in the GenBank database under accession
MH784952. ORF 1 (nucleotide position: 80 to 2,044) contains $1,965 \mathrm{nt}$ and encodes a predicted 71.5-kDa protein, which has been involved in virus movement and RNA silencing suppression for other tymoviruses (Bozarth et al. 1992; Chen et al. 2004). ORF 2 (nucleotide position: 87 to 5,630 ) encodes a $207-\mathrm{kDa}$ protein with methyltransferase, protease, helicase, and RNA-dependent RNApolymerase domains. ORF 3 (nucleotide position: 5,634 to 6,200) encodes the putative 188-amino-acid CP with an estimated molecular mass of $20 \mathrm{kDa}$.

A common feature in tymovirus genomes is the tymobox, a conserved 16-nt sequence hypothesized to be involved in the synthesis of the subgenomic RNA for CP expression (Ding et al. 1990). The


Fig. 4. Phylogenetic analysis of amino acid sequences using the maximum likelihood method. The bootstrap consensus tree inferred from 1,000 replicates is shown. Topology inferred for the A, replicase and for the B, coat protein. The Naranjilla mild mosaic virus (NarMMV; accession number MH784952) taxon is shown by the arrow. Abbreviations and National Center for Biotechnology Information accession numbers are as follows: BmMLV = Bombyx mori macula-like latent virus (AB186123), GFkV = Grapevine fleck macula virus (AJ309022), PnMV = Poinsettia mosaic virus (AB550790), OLV-3 = Olive latent marafivirus 3 (FJ444852), OBDV = Oat blue dwarf marafivirus (OBU87832), ELV = Erysimum latent virus (AF098523), OkMV = Okra mosaic virus (EF554577), KYMV = Kennedya yellow mosaic virus (NC001746), DuMV = Dulcamara mottle virus (AY789137), ChMV = Chayote mosaic virus (AF195000), ToYBV = Tomato yellow blotch virus (EU779803), APLV = Andean potato latent virus (JX508291), ToBMV = Tomato blistering mosaic virus (KC840043), APMMV = Andean potato mild mosaic virus (JX508290), EMV = Eggplant mosaic virus (KJ690172), NarCMV = Naranjilla chlorotic mosaic virus (MG323924), ChiYMV = Chiltepin yellow mosaic virus (FN563124), AVYV = Anagyris vein yellowing virus (AY751780), PIMV = Plantago mottle virus $($ AY751779), ScrMV = Scrophularia mottle virus (AY751777), OYMV = Ononis yellow mosaic virus (J04375), NeRNV = Nemesia ring necrosis virus (AY751778), GSyV-1 = Grapevine syrah virus-1 (marafivirus; KP221256), PeVD = Peach marafivirus D (KY084481), MRFV = Maize rayado fino marafivirus (KM523134), BIVS = Blackberry marafivirus $S$ (FJ915122), and NeVM = Nectarine marafivirus $M$ (KT273411).

Table 2. Summary of naranjilla mild mosaic virus (NarMMV) survey

\begin{tabular}{|c|c|c|c|c|c|c|}
\hline \multirow[b]{3}{*}{ Year of sampling } & \multirow[b]{3}{*}{ Province } & \multirow[b]{3}{*}{ Orchard $^{\mathbf{a}}$} & \multicolumn{4}{|c|}{ Virus detection by RT-PCR (positives/tested samples) ${ }^{\text {b }}$} \\
\hline & & & \multicolumn{2}{|c|}{ Naranjilla } & \multicolumn{2}{|c|}{ Tamarillo } \\
\hline & & & NarMMV & NarCMV & NarMMV & NarCMV \\
\hline 2017 & Pichincha & P1 & $48 / 60$ & $0 / 60$ & $2 / 20$ & $0 / 20$ \\
\hline \multirow[t]{3}{*}{2018} & Tungurahua & $\mathrm{T} 1$ & $8 / 30$ & $0 / 30$ & $0 / 30$ & $0 / 30$ \\
\hline & & $\mathrm{T} 2$ & $4 / 30$ & $0 / 30$ & $0 / 20$ & $0 / 20$ \\
\hline & Azuay & A1 & NT & NT & $0 / 20$ & $0 / 20$ \\
\hline
\end{tabular}

${ }^{\mathrm{a}} \mathrm{P}=$ Pichincha, $\mathrm{T}=$ Tungurahua, and $\mathrm{A}=$ Azuay.

${ }^{\mathrm{b}} \mathrm{RT}-\mathrm{PCR}=$ reverse transcription polymerase chain reaction, NarCMV $=$ naranjilla chlorotic mosaic virus, and $\mathrm{NT}=$ not tested. 
tymobox 5-GAGTCTGAATTGCTCA-3 is present in NarMMV, located upstream of the $\mathrm{CP}$ start codon, spanning nucleotide positions 5,601 to 5,616. The $3^{\prime}$ terminal region is composed of $148 \mathrm{nt}$, which is predicted to form tRNA-like structures (Gruber et al. 2008) with the valine anticodon CAC exposed in one of the loops (Fig. 3). This genome feature has been shown to have multiple roles in the replication of several tymoviruses (Dreher 2009).

BLASTn analyses using the complete genome sequence showed the highest nucleotide identities between NarMMV and ChYMV (74\%), followed by NarCMV (70\%) and eggplant mosaic virus (EMV) (68\%). The species demarcation criteria within the genus Tymovirus is $<80 \%$ overall nucleotide identity at the genome level (Dreher et al. 2012). The nucleotide identities observed between the newly assembled genome and its closest relatives place NarMMV as a distinct species in the genus Tymovirus.

At the amino acid level, the identities observed for the $207-\mathrm{kDa}$ replicase protein were $70 \%$ with NarCMV, followed by $68 \%$ identity with both ChYMV and EMV. For the CP, the highest identity was found with ChYMV (90\%), followed by NarCMV (80\%) and EMV (76\%). The movement protein showed similar amino acid sequence identities (approximately 47\%) with their counterparts from NarCMV, ChYMV, and EMV. The best evolutionary models for the replicase and CP were the rtREV+G+I (Dimmic et al. 2002) and Le-Gascuel_2008 (Le and Gascuel 2008), respectively. Phylogenetic relationships, inferred for both proteins, indicated that NarMMV is related most closely to ChYMV in a clade shared with NarCMV, EMV, and Andean potato mild mosaic virus (Fig. 4).

Transmission electron microscopy. Virions of approximately $30 \mathrm{~nm}$ in diameter, representing both empty and intact isometric particles, were observed in extracts from symptomatic naranjilla leaves. No other types of virus particles were observed under an electron microscope using negative staining (Supplementary Fig. S1). This morphology and the presence of intact and empty particles was consistent with the infection caused by a tymovirus (Koenig and Lesemann 1979).

Virus detection and prevalence in naranjilla and tamarillo orchards. Based on their performance in the laboratory tests, primers (forward: 5'-CGATCCTCTTCAGGGTGAATACC-3'; reverse: 5'CCAATCTCTCGTCGATTGGAGA-3') were selected to detect NarMMV in naranjilla and tamarillo field samples. This primer pair amplifies a 716-nt fragment of the helicase. The IC-RT-PCR assay, using the coating antibodies developed against NarCMV, detected NarMMV in both naranjilla and tamarillo samples, supporting the genetic relatedness between the two viruses (Supplementary Fig. S2). Because of the lack of NarCMV-positive samples in these surveys, however, an IC-duplex RT-PCR assay for the simultaneous detection of both NarMMV and NarCMV could not be tested during this study.

Surveys conducted in 2017 found NarMMV in $80 \%$ of naranjilla plants tested $(n=60)$ in one orchard of Pichincha Province, whereas only two of 20 tamarillo samples were positive. The NarMMVinfected naranjilla had moderate mosaic symptoms, but the tamarillo had severe leaf deformation and mottling. Additional testing in 2018 detected NarMMV in $20 \%$ of naranjilla plants tested $(n=60)$ from two orchards in a different province, Tungurahua. In tamarillo, the virus was not detected in any of the 70 symptomatic samples collected from orchards in Tungurahua and Azuay provinces (Table 2).

\section{Discussion}

Naranjilla and tamarillo are two important crops for hundreds of small-scale growers in subtropical areas of the Ecuadorean Andes. The fruit is consumed fresh or processed for juice by local industries. Its unique flavor has been well received by visitors from all over the world, opening the possibility for an export market (U.S. Department of Agriculture 2017). Despite the expansion of growing areas and the increase in consumption, data on viral diseases affecting naranjilla and tamarillo are rather scarce.

Recently, a new tymovirus, NarCMV, was found in the hybrid Puyo, the most commonly cultivated naranjilla in the Pastaza Province of Ecuador (Green et al. 2018). The present study describes a closely related, but distinct, tymovirus from naranjilla plants showing mild mosaic, collected from two different provinces in Ecuador, Pichincha and Tungurahua. The virus, provisionally named NarMMV, was found readily transmitted by mechanical inoculation to several other solanaceous hosts, where a range of symptoms were observed (Table 1). Genome sequence comparisons showed that NarMMV and its closest relatives share identities below the threshold established for species demarcation in the Tymovirus genus (Dreher et al. 2012). Symptoms induced by NarMMV are less prominent in naranjilla compared with those caused by NarCMV (Green et al. 2018). In tamarillo, NarMMV induced severe symptoms in the red cultivar, but none in the orange cultivar.

The limited survey conducted in this study found NarMMV in naranjilla and tamarillo orchards in two provinces, Pichincha and Tungurahua, whereas NarCMV was not found in any of the sampled orchards. This may reflect a different geographic origin and/or distribution of the two viruses in Ecuador, as NarCMV was first reported from a symptomatic plant in the Pastaza province (Supplementary Fig. S3) (Green et al. 2018).

The identification of NarMMV is the second report of a tymovirus infecting naranjilla and supports efforts to implement virus screening schemes for tropical crop propagation and breeding programs. The vegetative propagation of the naranjilla hybrids is probably the primary means for dissemination of this virus in the field. The low incidence of NarMMV in red tamarillo, along with the severity of symptoms induced by mechanical inoculation, is especially interesting because it suggests that this crop might be an alternative host for NarMMV under natural conditions and that an insect vector may be involved in transmission. Further studies on the epidemiology of tymoviruses of both naranjilla and tamarillo are warranted. The observation that NarMMV crossreacts with antibodies made against NarCMV offers the opportunity to use ELISA and/or IC-RT-PCR to expedite such investigations.

\section{Acknowledgments}

The authors thank J. Mowery for assisting with transmission electron microscopy photography and Dr. Gary Kinard for critical review of this manuscript.

\section{Literature Cited}

Bozarth, C. S., Weiland, J. I., and Dreher, T. W. 1992. Expression of ORF-69 of turnip yellow mosaic virus is necessary for viral spread in plants. Virology 187:124-130.

Chen, J., Li, W. X., Xie, D., Peng, J. R., and Ding, S. W. 2004. Viral virulence protein suppresses RNA silencing-mediated defense but upregulates the role of microRNA in host gene expression. Plant Cell 16:1302-1313.

Chikh-Ali, M., Gray, S. M., and Karasev, A. V. 2013. An improved multiplex IC-RTPCR assay distinguishes nine strains of potato virus Y. Plant Dis. 97:1370-1374.

Dennis, F. G., Jr., Herner, R. C., and Camacho, S. 1985. Naranjilla: A potential cash crop for the small farmer in Latin America. Acta Hortic. 158:475-481.

Dimmic, M. W., Rest, J. S., and Mindell, D. P. 2002. rtREV: An amino acid substitution matrix for inference of retrovirus and reverse transcriptase phylogeny. J. Mol. Evol. 55:65-73.

Ding, S., Howe, J., Keese, P., Mackenzie, A., Meek, D., Osorio-Keese, M. Skotnicki, M., Srifah, P., Torronen, M., and Gibbs, A.1990. The tymobox, a sequence shared by most tymoviruses: Its use in molecular studies of tymoviruses. Nucleic Acids Res. 18:1181-1187.

Dreher, T. W., Edwards, M. C., Gibbs, A. J., Haenni, A.-L., Hammond, R. W., Jupin, I., Koenig, R., Sabanadzovic, S., and Martelli, G. P. 2012. Family Tymoviridae. Pages 944-952 in: Virus Taxonomy: Ninth Report of the International Committee on Taxonomy of Viruses. A. M. Q. King, M. J. Adams, E. B. Carstens, and E. J. Lefkowitz, eds. Elsevier, Amsterdam, Netherlands.

Dreher, T. W. 2009. Role of tRNA-like structures in controlling plant virus replication. Virus Res. 139:217-229.

Edgar, R. C. 2004. MUSCLE: Multiple sequence alignment with high accuracy and high throughput. Nucleic Acids Res. 32:1792-1797.

Espinoza, D., Viera, W., Debut, A., Vásquez, W., and Ayala, L. 2017. Virus diagnosis in tree tomato (Solanum betaceum Cav.) by RT-PCR and transmission electron microscopy in Pichincha and Tungurahua Provinces of Ecuador. Agron. Colomb. 35:35-43.

Green, K. J., Mollov, D., Tran, L. T., Alvarez-Quinto, R. A., Ochoa, J. B., QuitoAvila, D. F., and Karasev, A. V. 2018. Characterization of a new tymovirus causing stunting and chlorotic mosaic in naranjilla (Solanum quitoense). Plant Dis. 102:911-918.

Gruber, A. R., Lorenz, R., Bernhart, S. H., Neuböck, R., and Hofacker, I. L. 2008 The Vienna RNA web suite. Nucleic Acids Res. 36:W70-W74.

Halgren, A., Tzanetakis, I. E., and Martin, R. R. 2007. Identification, characterization, and detection of Black raspberry necrosis virus. Phytopathology 97:44-50. 
Heiser, C. B., and Anderson, G. 1999. "New" Solanums. Pages 379-384 in: Perspectives on New Crops and New Use. American Society for Horticultural Science, Alexandria, VA.

Hull, R. 2009. Mechanical inoculation of plant viruses. Curr. Protoc. Microbiol. 13:16B.6.1-16B.6.4.

Insuasti, M. L., Ochoa, J. B., Martin, R. R., Alvarez, R. A., and Quito-Avila, D. F. 2016. First report of Potato virus $V$ and Peru tomato mosaic virus on tamarillo (Solanum betaceum) orchards of Ecuador. Plant Dis. 100: 868.

Koenig, R., and Lesemann, D.-E. 1979. Tymovirus Group: Descriptions of Plant Viruses, No. 214. Association of Applied Biologists, Wellesbourne, Warwick, UK. http://www.dpvweb.net/dpv/showdpv.php?dpvno=214

Kumar, S., Stecher, G., and Tamura, K. 2016. MEGA7: Molecular evolutionary genetics analysis version 7. 0 for bigger datasets. Mol. Biol. Evol. 33: 1870-1874.
Le, S. Q., and Gascuel, O. 2008. An improved general amino acid replacement matrix. Mol. Biol. Evol. 25:1307-1320.

Lim, T. K. 2013. Edible Medicinal and Non-Medicinal Plants. Volume 6, Fruits. Springer, Dordrecht, Netherlands.

Monteros, A., Muñoz, L., Revelo, J., Tapia, C., Zambrano, E., Fiallos, J., and Kodym, A. 2004. Nematode resistance through mutation induction in a local variety of naranjilla (Solanum quitoense Lam) in Ecuador. Pages 87-99 in: Genetic Improvement of Under-utilized and Neglected Crops in Low Income Food Deficit Countries Through Irradiation and Related Techniques. International Atomic Energy Agency, Pretoria, South Africa.

U.S. Department of Agriculture. 2017. APHIS proposes to allow tree tomatoes from Ecuador to be imported into the continental United States. Animal and Plant Health Inspection Service Stakeholder Information APHIS-2015-0072. https://www.aphis.usda.gov/aphis/newsroom/stakeholder-info/sa_by_date/sa2017/june/ecuador-tree-tomatoes 